\title{
人工受粉および受粉用品種の高接ぎがカキ‘早秋’の生理落果に及ぼす影響
}

\author{
鈴木哲也**新川 猛 \\ 岐阜県農業技術センター 501-1152 岐阜市又丸
}

\section{Effects of Artificial Pollination and Grafting of Pollen Cultivar on Physiological Fruit Drop in 'Soshu' Persimmon}

\author{
Tetsuya Suzuki* and Takeshi Niikawa \\ Gifu Prefectural Agricultural Technology Center, Gifu 501-1152
}

\begin{abstract}
'Soshu' persimmon is a very early maturing variety of the pollination constant non-astringent type, which has red skin color and excellent eating quality. Therefore 'Soshu' gets a high market valuation. 'Soshu' often exhibits physiological fruit drop in the early stage (June to July), and is known to have a variable fruit set. In this study, we investigated the effects of artificial pollination and grafting of the pollen cultivar on the physiological fruit drop of 'Soshu'. The pollinizer cultivar 'Saefuji' was used because it was suitable for artificial pollination of 'Soshu'. Artificial pollination with pure pollen of 'Saefuji' and grafting of 'Saefuji' had some preventive effects on physiological fruit drop; however, some variations in their effectiveness were observed due to annual changes. To identify a more stable prevention method, we examined the relationship between physiological fruit drop and the length of the shoot at the terminus of the primary scaffold branch. Shortening the shoot at the terminal of the primary scaffold branch prevented physiological fruit drop in June.

However, physiological fruit drop increased afterwards. From the above, we revealed that artificial pollination with pure pollen, grafting of the pollen cultivar, and shortening of the shoot at the terminal of the primary scaffold branch were efficient techniques for the prevention of physiological fruit drop. It is important to develop methods for the prevention of physiological fruit drop with an annual change by combining these techniques.
\end{abstract}

Key Words : fruit quality, fruit set, seed development

キーワード：果実品質，結実，種子形成

\section{緒言}

岐阜県に扮いて，市場評価の低下した ‘西村早生’に代 わり, “早秋’が本格的に導入されたのは2004年頃であっ た. ‘西村早生’ は不完全甘ガキであり，渋果が混入しや すいこと, 果肉が硬く食味が不良であることから, 市場評 価の低下を招いた. 一方, “早秋” は極早生の完全甘ガキで あること, 果皮色は赤く, 良食味であることから（山田 ら，2004）, 高い市場評価を得た。 しかし, 生理落果の発 生が多く，結実の安定しないことが課題であった.

カキの生理落果には早期落果と後期落果があり, ‘太秋” を除いて “富有”など主要甘ガキ品種では, 後期落果の発 生はほとんど認められず, 早期落果が問題になる。早期落 果については, 種子形成力と単為結果力に品種間差異のあ ること（梶浦, 1941; 山田ら, 1987), 日射量不足（梶浦, 1942a），果実と枝葉間の養分競合（北島ら，1987）などが 主な発生要因とされ，植物ホルモンとの関係（傍島ら，

2016 年 12 月 27 日 受付. 2017 年 6 月 6 日 受理.

* Corresponding author. E-mail: suzuki-tetsuya@pref.gifu.lg.jp
1969; 壽松木ら, 1989; 薬師寺・長谷, 1991）も報告されて いる。 また，生理落果防止技術としては，“伊豆”に打け る着果制限や人工受粉（堀江ら，1988），“刀根早生’，“新 秋’に扣ける摘蕾や人工受粉（文室, 2003), “刀根早生” に打ける環状はく皮（矢野ら，1999）などが報告されて いる.

“早秋”も問題になるのは早期落果である。 そのピーク は 6 月と 7 月に現れ，6月の落果が落果全体の多くを占め ている（千々和，2009）。北島（2000）は，カキの早期落果 のらち, 早い時期の落果は不受精の無核果実が多く，有核 果実の落果はやや遅れて生じると報告している。 また, 千々和（2009）は，“早秋’の早期落果の5ち，6月に落果 するほとんどの果実で種子が形成されていないことを示し た.このことから，“早秋’の生理落果防止には種子形成 を促進することが重要である，そこで，本研究では，人工 受粉の花粉希釈倍率ならびに受粉用品種の高接ぎが ‘早 秋’の生理落果に及ぼす影響を検討した。 また，主枝先端 新梢長を用いて，その伸長程度と生理落果との関係を明ら かにした。 


\section{材料および方法}

\section{1. 人工受粉による生理落果への影響}

\section{1）花粉用品種の雄花における花粉収量, 花粉発芽率およ} び開花期の違い（実験 1)

2007，2008 年に岐阜県農業技術センタ一植栽のそれぞれ 樹齢 35, 36 年生 ‘赤柿’, 樹齢 32, 33 年生 “サエフジ’ 打 よび高接ぎ 11,12 年目 “禅寺丸’ の雄花を供試し, 花粉収 量，花粉発芽率および開花期を調査した。

“赤柿’と“サエフジ’ は2 2007 年 5 月 16 日，2008 年 5 月 12 日，“禅寺丸’は2007年 5 月 20 日，2008年 5 月 15 日の 午前 9 時までに開花した雄花を採取した。 その雄花を $25^{\circ} \mathrm{C}$ の開葯器（M-500ET 型, (株) ミッワ) 内に 24 時間放 置して開葯させ，花粉を採取し，50花分の花粉収量を調 査した. 採取した花粉は薬包紙で約 $200 \mathrm{mg}$ ずつ包装して, シリカゲルを入れた $300 \mathrm{~mL}$ 容量のスチロール製容器に密 閉して $-20^{\circ} \mathrm{C} て ゙$ 冷凍貯蔵し, 花粉採取日おょび貯蔵後 4 日 に花粉発芽率を調査した。花粉をショ糖 $15 \%$ 含有 $1 \%$ 寒天 培地に置床し, $25^{\circ} \mathrm{C}$ のインキュベータ一内に 24 時間放置 した後, 観察花粉数約 100 粒を 1 反復として, 5 反復調査 した. 開花期は育成系統適応性検定試験 - 特性検定試験調 査方法（独立行政法人農業 - 食品産業技術総合研究機構果 樹研究所，2007）の雌花開花期に準じて調査した. な报, ‘早秋’の開花期は 2007，2008 年にそれぞれ高接ぎ 10，11 年目の樹を調査した.

\section{2）花粉希釈倍率が生理落果に及ぼす影響（実験 2）}

2009，2010，2011 年に岐阜県農業技術センタ一植栽のそ れぞれ接ぎ木後 $8,9,10$ 年生の“早秋” 5 樹を供試した。 供試樹は 2002 年に“早秋”を 2 年生“前川次郎”苗に接ぎ 木した樹で, 栽植密度は樹間 $3.5 \mathrm{~m} \times$ 列間 $3.5 \mathrm{~m}$, 仕立て方 法は 3 本主枝の開心自然形とし，栽培管理は岐阜県標準技 術体系（岐阜県，2005）に準じた.

試験区は人工受粉区，自然受粉区，無受粉区とし，2009 年の人工受粉区は純花粉区抢よび 10 倍希釈区，2010，2011 年の人工受粉区は純花粉区，3 倍希釈区，5倍希釈区未よ び 10 倍希釈区とした。供試した花は，個体差による影響 を小さくするために条件を揃えた． 樹冠外周部に位置する 長さ $30 \sim 40 \mathrm{~cm}$ の結果母枝の中で，頂芽拈よび下位節を 除いて斜め上方に伸びた新梢に着生した花を供試した。各 試験区は 30 花，樹当たり 6 花を 1 区として 5 反復とした. な拈，人工受粉に用いた品種は，実験 1 の結果から“早秋” の開花期と合ら“サエフジ’とした.

人工受粉用の ‘サエフジ’ 雄花の採取は 2009 年 5 月 13 日，2010年 5 月 21 日，2011 年 5 月 23 日に行った. 花粉の 採取扣よび貯蔵方法は実験 1 と同様とした。 人工受粉は 2009 年 5 月 15,18 日，2010 年 5 月 25, 27 日，2011 年 5 月 25, 26 日に, 冷凍貯蔵した花粉を石松子で試験倍率に希釈 して筆で行った. 人工受粉にあたっては，他の花粉が受精 するのを防ぐため，小袋を開花前に被せ，受粉時に外し，
その後再び被せた．無受粉区においては開花前後に小袋を 被せた。

‘早秋’の開花盛期は 2009 年 5 月 18 日，2010年 5 月 24 日，2011 年 5 月 25 日であった。摘蕾は開花盛期約 $12 \sim 14$ 日前の 2009 年 5 月 6 日，2010年 5 月 10 日，2011 年 5 月 12 日に 1 新梢 1 蕾, 摘果は 2009 年 7 月 27 日, 2010 年 7 月 26 日，2011 年 7 月 21 日に葉果比 15 で実施した。

摘蕾後から 2009 年は 7 月 27 日，2010年は 7 月 22 日, 2011 年は 7 月 21 日まで定期的に着果数を調査して生理落 果率を求めた。2009年 9 月 30 日，2010年 10 月 1 日，2011 年 9 月 29 日に一斉収穫し, 全果実の果実品質を調査した.

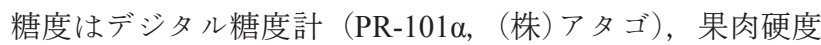
は果実硬度計（KM-5 型，(株) 藤原製作所）で測定した。 果皮色の測定には色彩色差計（CR-400, コニカミノルタ (株)）を使用した。新川ら（2008）の報告に準じて次式を 作成し, 測定した色相角度 $\left(\mathrm{H}^{\circ}\right)$ をカラーチャート值 $(\mathrm{CC}$ 值）に変換した。 $\mathrm{CC}$ 值 $=-8.806 \times \mathrm{LN}\left(\mathrm{H}^{\circ}\right)+42.083\left(\mathrm{r}^{2}=\right.$ 0.986). 奇形指数は果実の奇形度を 0 (無) 3 (甚) の 4 段 階に評価した平均値とした。

\section{2. 受粉用品種の高接ぎによる生理落果への影響（実験 3）}

2014，2015 年に岐阜県農業技術センタ一植栽のそれぞれ 樹齢 12，13 年生の“早秋’ 7 樹を供試した。供試樹は 2003 年に定植した“早秋”樹で，栽植密度は樹間 $4.5 \mathrm{~m} \times$ 列間 $3.5 \mathrm{~m}$, 仕立て方法は 3 本主枝の開心自然形とし，栽培管 理は岐阜県標準技術体系（岐阜県，2005）に準じた。なお， 樹齢 11 年生時の樹高は平均約 $3.0 \mathrm{~m}$ であった.

試験区は，2011 年 4 月，側枝の一部分に受粉用品種を 高接ぎした高接ぎ区と無処理区とし，高接ぎ区は 4 反復, 無処理区は 3 反復とした. な打 1 反復は 1 樹とした. 受粉 用品種は，実験 2 と同様の理由から“サエフジをを接ぎ木 した。“サエフジ’は‘早秋’樹の中央部に位置し，高接ぎ 2 年目から雄花が開花，4年目には接ぎ木部からの高さが 平均約 $2.0 \mathrm{~m}$ になった。 な打, “サエフジ’は無剪定とした.

‘早秋” の開花盛期は2014 年 5 月 20 日，2015 年 5 月 15 日であった。摘蕾は開花盛期 8～13 日前の 2014 年 5 月 7 日， 2015 年 5 月 7 日に 1 新梢 1 蕾，摘果は 2014 年 7 月 24 日，2015 年 7 月 21 日に葉果比 15 で実施した。

2014 年は摘蕾後から 7 月 23 日まで，2015 年は摘蕾後か ら 7 月 20 日まで，定期的に着果数を調查し，樹単位で生 理落果率を求めた。摘果日に果実調査用のラベルを 1 樹当 たり $10 〜 15$ 果無作為に設置し，2014年10月 3 日，2015 年 10 月 1 日に一斉収穫を行い，果実品質を調查した。調 査方法は実験 2 と同様とした.

\section{3. 主枝先端新梢長と生理落果との関係（実験 4)}

2008，2009年に岐阜県農業技術センタ一植栽のそれぞれ 樹齢 6,7 年生の ‘早秋’を 12, 7 樹供試した. 供試樹は実験 3 と同様であり, 樹齢 4 年生時の収穫果数は平均 10.7 果 / 樹, 収量は平均 $2.4 \mathrm{~kg} /$ 樹，5年生時の収穫果数は平均 9.0 果/ 樹，収量は平均 $2.3 \mathrm{~kg}$ /樹，樹高は平均約 $2.3 \mathrm{~m}$ であった. 
試験区は主枝先端新梢長ごとに樹単位で構成し, 各主枝 の先端新梢長の平均值を主枝先端新梢長とした，なお，主 枝先端新梢長に変化を与えるため, 内向きの側枝および徒 長枝の久を切除した弱剪定から結果母枝を約 $30 \mathrm{~cm}$ 間隔に 配置した強剪定まで強度を変えて剪定を行った．2008年 は $50 \mathrm{~cm}$ 末満, $50 \mathrm{~cm}$ 以上 $60 \mathrm{~cm}$ 末満, $60 \mathrm{~cm}$ 以上の 3 区, 2009 年は $50 \mathrm{~cm}$ 末満, $50 \mathrm{~cm}$ 以上 $60 \mathrm{~cm}$ 末満の 2 区とし, 2008 年の 3 区と 2009 年の $50 \mathrm{~cm}$ 未満区は各 4 反復, 2009 年の $50 \mathrm{~cm}$ 以上 $60 \mathrm{~cm}$ 未満区は 3 反復とした。 2009 年の $60 \mathrm{~cm}$ 以上区は使用できる樹が 2 樹しかなかったため, 試 験区から省いた。な拈， 1 反復は 1 樹とした。

開花盛期は 2008 年 5 月 19 日，2009年 5 月 17 日であっ た. 摘蕾は開花盛期約 10 日前の 2008 年 5 月 9 日, 2009 年 5 月 6 日に 1 新梢 1 蕾，摘果は 2008 年 7 月 22 日， 2009 年 7 月 27 日に葉果比 15 で実施した。

2008 年は摘蕾後から 7 月 18 日まで，2009年は摘蕾後か ら 7 月 22 日まで定期的に着果数を調査し, 樹単位で生理 落果率を求めた。 主枝先端新梢長, 新梢数, 不定芽由来の 新梢数と新梢長, 二次伸長率を 2008 年 6 月 26 日， 2009 年 6 月 25 日に調査した. 不定芽由来の新梢数は主枝抢よび 亜主枝上に発生した新梢数, 二次伸長率はすべての新梢の らち, 上述の調査日の時点で二次伸長していた割合とし た. 摘果日に果実調査用のラベルを 1 樹当たり $8 \sim 10$ 果 無作為に設置し，2008 年 10 月 5 日，2009年 10 月 1 日に一 斉收穫を行い, 果実品質を調査した。調查方法は実験 2 と 同様とした。幹周は, 落葉後, 接ぎ木部の上部約 $15 \mathrm{~cm} の$ 位置を測定した.

\section{結 果}

\section{1. 人工受粉による生理落果への影響}

1）花粉用品種の雄花における花粉収量, 花粉発芽率およ び開花期の違い（実験 1)

2007 年の花粉収量は“赤柿’, ‘サエフジ’, ‘禅寺丸’ もにほぼ同等であった(第 1 表)。2008年は“サエフジ， “禅寺丸” の花粉收量が ‘赤柿’よりも多く, ‘サエフジ’ と “禅寺丸”は注ぼ同等であった。

2007, 2008 年ともに, 品種による花粉発芽率への影響 は有意であったが，貯蔵日数による影響は認められなかっ た（第 1 表).

‘早秋’の開花期に対して, ‘サエフジ’の雄花は合って いたが, ‘赤柿’ の雄花はやや早く, “禅寺丸’ の雄花はや や遅かった(第 2 表).

\section{2）花粉希勫倍率が生理落果に及ぼす影響（実験 2）}

2009，2010年に抢いて, 純花粉区の生理落果率は自然受 粉区よりも低く推移した（第 1 図）．７月下旬の調査最終日 に打ける純花粉区と自然受粉区の生理落果率は, 2009 年 で $13.3 \%$ と 70.0\%，2010年で $46.7 \%$ と 83.3\%であった。 し かし，2011年に沶いて，純花粉区と自然受粉区の生理落 果率に有意差は認められなかった。 また，2009～2011年
第 1 表 花粉用品種の雄花における花粉収量および花粉発芽率

\begin{tabular}{|c|c|c|c|c|}
\hline & & $\begin{array}{l}\text { 粉収量 } \\
\text { (mg) }\end{array}$ & & $\begin{array}{c}\text { 花粉発芽率 } \\
(\%)\end{array}$ \\
\hline \multirow{6}{*}{2007 年 } & \multirow{2}{*}{ 赤柿 } & \multirow{2}{*}{124} & 採取日 & 20.4 \\
\hline & & & 貯蔵後 4 日 & 10.5 \\
\hline & \multirow{2}{*}{ サエフジ } & \multirow{2}{*}{133} & 採取日 & 32.1 \\
\hline & & & 貯蔵後 4 日 & 35.8 \\
\hline & \multirow{2}{*}{ 禅寺丸 } & \multirow{2}{*}{133} & 採取日 & 49.1 \\
\hline & & & 貯蔵後 4 日 & 52.3 \\
\hline & \multirow{3}{*}{ 分散分析 ${ }^{y}$} & & 品種 & $* *$ \\
\hline & & & 貯蔵日数 & $\mathrm{ns}$ \\
\hline & & & 交互作用 & $*$ \\
\hline \multirow{6}{*}{2008 年 } & \multirow{2}{*}{ 赤柿 } & \multirow{2}{*}{114} & 採取日 & 25.6 \\
\hline & & & 貯蔵後 4 日 & 17.6 \\
\hline & \multirow{2}{*}{ サエフジ } & \multirow{2}{*}{212} & 採取日 & 36.6 \\
\hline & & & 貯蔵後 4 日 & 28.7 \\
\hline & \multirow{2}{*}{ 禅寺丸 } & \multirow{2}{*}{228} & 採取日 & 59.8 \\
\hline & & & 貯蔵後 4 日 & 61.4 \\
\hline & \multirow{3}{*}{ 分散分析 ${ }^{y}$} & & 品種 & $* *$ \\
\hline & & & 貯蔵日数 & ns \\
\hline & & & 交互作用 & ns \\
\hline
\end{tabular}

${ }^{\mathrm{z}} 50$ 花分の花粉収量

y アークサイン変換後分散分析により，**は1\%水準，*は $5 \%$ 水準で有意差あり, $\mathrm{ns}$ は有意差なしを示す $(n=5)$

第2 表 ‘早秋’ および花粉用品種の雄花の開花期

\begin{tabular}{|c|c|c|c|c|}
\hline & & 開花始期 & 開花盛期 & 開花終期 \\
\hline \multirow{4}{*}{2007 年 } & 早秋 & 5 月 18 日 & 5 月 20 日 & 5 月 23 日 \\
\hline & 赤柿（雄花） & 5 月 12 日 & 5 月 15 日 & 5 月 20 日 \\
\hline & サエフジ（雄花） & 5 月 14 日 & 5 月 16 日 & 5 月 22 日 \\
\hline & 禅寺丸（雄花） & 5 月 20 日 & 5 月 24 日 & 5 月 28 日 \\
\hline \multirow{4}{*}{2008 年 } & 早秋 & 5 月 13 日 & 5 月 15 日 & 5 月 18 日 \\
\hline & 赤柿（雄花） & 5 月 8 日 & 5 月 11 日 & 5 月 18 日 \\
\hline & サエフジ（雄花） & 5 月 11 日 & 5 月 14 日 & 5 月 18 日 \\
\hline & 禅寺丸（雄花） & 5 月 15 日 & 5 月 17 日 & 5 月 20 日 \\
\hline
\end{tabular}

に扬いて，3 倍，5倍，10 倍希勫区と自然受粉区の生理落 果率に有意差は認められなかった。

2009年の種子数を除き，2009～2011年に打いて，花粉 希釈倍率による果実品質の差は認められなかった（第3 表).

\section{2. 受粉用品種の高接ぎによる生理落果への影響（実験 3）}

高接ぎした受粉用品種 ‘サエフジ’の開花期（始期〜終 期）は 2014年 5 月 16 23 日，2015年 5月 11〜 17 日であ り，両年とも ‘早秋’ の開花期に合っていた.

2015 年は 6 月中旬以降，6月 29 日と7月 6 日を除いて高 接ぎ区の生理落果率が無処理区よりも低く推移した（第 2 図). 2014 年は調査最終日の 7 月 23 日に招いて高接ぎ区の 

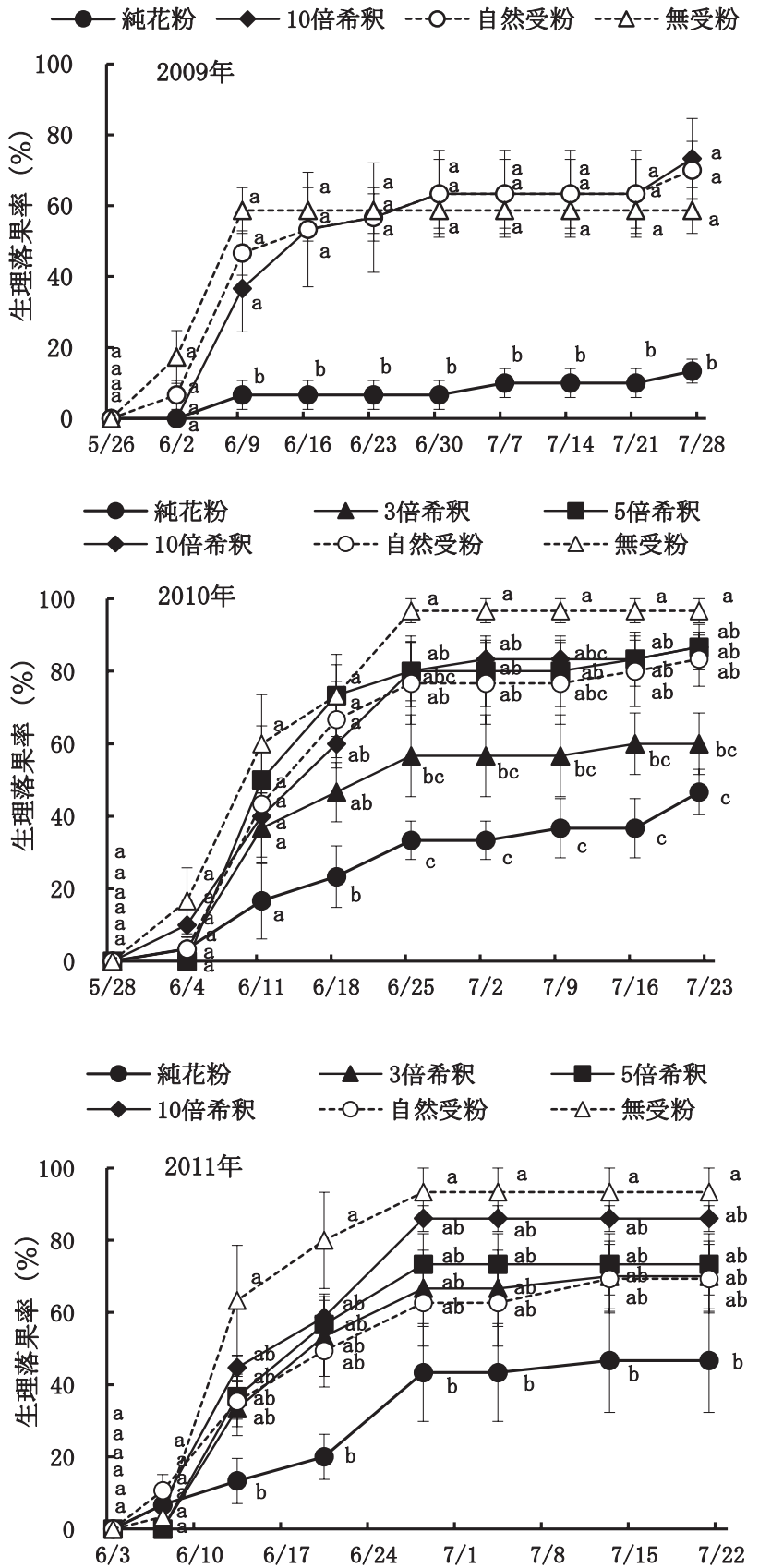

第 1 図人工受粉の花粉希釈倍率が生理落果率に及ぼす影響 (上段：2009年，中段 : 2010 年，下段：2011年） 縦線は標準䛊差を示す $(n=5)$ アークサイン変換後 Tukey の多重検定により, 同一調 査日の異符号間は 5\%水準で有意差あり

生理落果率が無処理区よりも低かった．7月下旬の調査最 終日に打ける高接ぎ区と無処理区の生理落果率は, 2014 年で $15.8 \%$ と 27.8\%，2015 年で $13.2 \%$ と 25.6\%であった.

2014，2015 年ともに，高接ぎ区と無処理区との間に果実 品質および収量の差は認められなかった（第 4 表）.

\section{3. 主枝先端新梢長と生理落果との関係（実験 4)}

主枝先端新梢長の平均は2008年の $50 \mathrm{~cm}$ 未満区で $36.8 \pm 5.0 \mathrm{~cm}$ (平均值 \pm 標準偏差), $50 \mathrm{~cm}$ 以上 $60 \mathrm{~cm}$ 未満
区で $53.8 \pm 3.0 \mathrm{~cm}, 60 \mathrm{~cm}$ 以上区で $73.2 \pm 4.9 \mathrm{~cm}, 2009$ 年の $50 \mathrm{~cm}$ 末満区で $36.5 \pm 4.8 \mathrm{~cm}, 50 \mathrm{~cm}$ 以上 $60 \mathrm{~cm}$ 末満区で $56.8 \pm 3.3 \mathrm{~cm}$ であった.

2008 年に扮いて，6月 2～23 日の生理落果率は，主枝 先端新梢長 $60 \mathrm{~cm}$ 以上区が $50 \mathrm{~cm}$ 未満区扔よび $50 \mathrm{~cm}$ 以上 $60 \mathrm{~cm}$ 末満区よりも高く推移した (第 3 図). $50 \mathrm{~cm}$ 末満区 と $50 \mathrm{~cm}$ 以上 $60 \mathrm{~cm}$ 未満区との間に差は認められなかった. 6 月 30 日以降，各区の生理落果率に差は認められず，調 查最終日の 7 月 18 日に抢战生理落果率は $40 \sim 60 \%$ の範 囲であった。

2009 年に扮いて，6月 15 日～7月 7 日の生理落果率は, 主枝先端新梢長 $50 \mathrm{~cm}$ 以上 $60 \mathrm{~cm}$ 未満区が $50 \mathrm{~cm}$ 未満区よ りも高く推移した（第 3 図）。7月 14 日以降，両区の生理 落果率に差は認められず，調查最終日の 7 月 22 日に打け る生理落果率は 35〜 45\%の範囲であった。

2008，2009年ともに，主枝先端新梢長の違いによる結果 母枝数, 新梢数, 二次伸長率拈よび幹周の差は認められな かった (第 5 表)，不定芽由来の新梢数と新梢長について は，2008年に一部差が認められたが，2009年に差は認め られなかった（第 5 表）。また，果実品質拉よび収量の差 も認められなかった（第6表）。

\section{考察}

岐阜県に“早秋’が本格導入されたのは2004年頃であ り，その後，苗木の成長に伴い生産量は増加すると予測さ れた。しかし，生理落果の多発生なぞもあり，予測したと 打りには増加しなかった。“早秋’ は種子形成力, 単為結 果力ともに高くないこと（山田ら，2004），産地内にあっ た受粉樹は樹高が高く，枝葉が混んでいたため，フジコナ カイガラムシなど害虫の発生源になりやすく，多くが伐 採されていたことなどから，生理落果が多発したと考兄ら れた。

積極的に種子形成を図るため，人工受粉による生理落果 への影響を実験した。2 $007 ， 2008$ 年に“早秋’の人工受粉 に適した花粉用品種の検討を行った。“禅寺丸”は“サエフ ジ，“赤柿’よりも花粉発芽率が高かったが，本実験では ‘早秋’の開花期と合わなかったため，花粉用品種は開花 期の合った“サエフジ’とした(第 1，2 表)．2009～2011 年に ‘サエフジ’を用いて，人工受粉の花粉希釈倍率を検 討した．2009，2010年は，純花粉区の生理落果率が自然受 粉区よりも低く推移したが，2011 年は，純花粉区と自然 受粉区との間に差が認められなかった（第 1 図）。生理落 果の要因としては，光条件，植物成長調節物質，種子形成 と果実のシンクカ, 果実と栄養器官との競合があり（北島, 2000)，年によっては純花粉による人工受粉のみで生理落 果を防ぐのは困難であると考兄られた。

また，純花粉区の結実が 2010 年，2011 年よりも相対的 飞高かった 2009 年は，5月 3 日に新梢停止期となり，2010 年の 5 月 17 日, 2011 年の 5 月 18 日に比べて著しく早かっ 
第 3 表 人工受粉の花粉希釈倍率が果実品質に及ぼす影響

\begin{tabular}{|c|c|c|c|c|c|c|c|}
\hline & 試験区 & $\begin{array}{c}\begin{array}{c}\text { 果重 } \\
(\mathrm{g})\end{array} \\
\end{array}$ & $\begin{array}{c}\text { 果頂部果皮色 } \\
\text { (CC 值) }\end{array}$ & $\begin{array}{l}\text { 糖度 } \\
\left({ }^{\circ} \text { Brix }\right)\end{array}$ & $\begin{array}{l}\text { 果肉硬度 } \\
\left(\mathrm{kg} / \mathrm{cm}^{2}\right)\end{array}$ & $\begin{array}{l}\text { 種子数 } \\
\text { (個) }\end{array}$ & 奇形指数 ${ }^{\mathrm{z}}$ \\
\hline \multirow{4}{*}{2009 年 } & 純花粉区 & 249.7 & 8.3 & 16.3 & 2.3 & $2.4 \mathrm{a}^{\mathrm{y}}$ & 0.4 \\
\hline & 10 倍希釈区 & 217.9 & 8.2 & 16.1 & 2.2 & $0.3 \mathrm{~b}$ & 0.0 \\
\hline & 自然受粉区 & 228.4 & 8.1 & 16.7 & 2.2 & $1.4 \mathrm{ab}$ & 0.7 \\
\hline & 無受粉区 & 222.8 & 8.4 & 16.8 & 2.1 & $0.0 \mathrm{~b}$ & 0.6 \\
\hline & 有意差 ${ }^{x}$ & ns & ns & ns & ns & $*$ & ns \\
\hline \multirow{6}{*}{2010 年 } & 純花粉区 & 219.4 & 5.2 & 14.2 & 2.4 & 2.5 & 0.1 \\
\hline & 3 倍希釈区 & 219.1 & 5.3 & 15.2 & 2.5 & 2.1 & 0.5 \\
\hline & 5 倍希釈区 & 209.9 & 5.9 & 15.1 & 2.3 & 2.0 & 0.0 \\
\hline & 10 倍希釈区 & $-{ }^{\mathrm{w}}$ & - & - & - & - & - \\
\hline & 自然受粉区 & 232.2 & 5.4 & 14.9 & 2.1 & 1.2 & 0.4 \\
\hline & 無受粉区 & - & - & - & - & - & - \\
\hline & 有意差 ${ }^{x}$ & ns & ns & ns & ns & ns & ns \\
\hline \multirow{6}{*}{2011 年 } & 純花粉区 & 270.6 & 6.1 & 14.9 & 2.2 & 1.4 & 0.0 \\
\hline & 3 倍希釈区 & 263.7 & 6.2 & 15.2 & 1.8 & 1.7 & 0.1 \\
\hline & 5 倍希釈区 & 253.0 & 5.5 & 14.9 & 2.1 & 0.9 & 0.1 \\
\hline & 10 倍希釈区 & 266.7 & 5.4 & 14.2 & 1.8 & 0.5 & 0.3 \\
\hline & 自然受粉区 & 264.6 & 5.3 & 14.9 & 2.2 & 1.6 & 0.0 \\
\hline & 無受粉区 & - & - & - & - & - & - \\
\hline & 有意差 ${ }^{x}$ & ns & ns & ns & ns & ns & ns \\
\hline
\end{tabular}

$\mathrm{z}$ 奇形指数は果実の奇形度を 0 (無) 〜 3 (甚) の 4 段階に評価した平均値

${ }^{\mathrm{y}}$ Tukey-Kramerの多重検定により，異符号間に5\%水準で有意差あり

$\mathrm{x}$ 分散分析により， ns は有意差なし，*は $5 \%$ 水準で有意差あり $(\mathrm{n}=5)$

$\mathrm{w}$ 調査果数が 5 果以下のため, データ省略

た.このことから，新梢停止が早い樹の状態で純花粉によ る人工受粉を行らと，確実に生理落果を抑制できると考光 られた．カキに和都生理落果の発生要因として樹体の栄 養不良や枝葉と果実との養分競合などがあることから（梶 浦，1942b; 北島ら，1987), 新梢停止期が早い注ど生理落 果するまでの果実への光合成産物の蓄積量が増すと推察さ れ，生理落果率が低かったと考兄られた。ささらに，2009 年は二次伸長率が低かったことからも(第 5 表)，枝葉と 果実との養分競合が少なく, 生理落果率が低かったと考兄 られた。

一方，3倍，5倍および 10 倍希釈の人工受粉による生理 落果率は自然受粉と差が認められず (第 1 図), 生理落果 防止の効果は認められなかった。 これらの結果から, “サ エフジ’の純花粉による人工受粉は年次変動を生じるが, 生理落果防止にある程度の効果があると考光られた。これ は, 八ウス栽培 ‘早秋’ に打いて, 純花粉による人工受粉 を行らと着果率が向上するとの報告（杉村，2008）と一致 した。 また，林（2000）が, ‘伊豆”の人工受粉について, 純花粉〜 5 倍希釈で実施するよう示していることからも， 種子形成力の弱、品種に扔汀る人受粉は純花粉もしくは 低倍率で行ら必要があると考えられた。

“富有”に扣ける受粉樹の混植本数は $10 \mathrm{a}$ 当たり $4 \sim 5$ 本 である (岐阜県, 2005)。“富有”よりも種子形成力の弱い
“早秋”に执いて，“富有”之同程度の受粉樹の混植本数で は結実が不安定になりやすい可能性がある。そこで，多く の受粉樹を早急に確保する方法として，“早秋’樹の側枝 に受粉用品種の ‘サエフジ”を高接ぎする方法について実 験した，高接ぎ区の生理落果率は無処理区よりも，2015 年は 6 月中旬以降一部を除いて低く推移したが，2014年 は調查最終日の 7 月 23 日の久低かった（第 2 図）。このこ とから，“サエフジ’の高接ぎは年次変動を生じるが，生理 落果防止にある程度の効果があると考学られた．年次変動 の要因を検討するため, 2014 と 2015 年の開花前 10 日間, 開花期間，6 7月の気象条件（気温，日照時間，降水量）, 生育ステージなぞを調べたが，明らかな差は認められず， その要因は判然としなかった.

受粉用品種の高接ぎによって, ある程度の生理落果防止 効果は認められたが，収穫果数や収量に影響は認められな かった (第 4 表)。これは，いずれの試験区に扔いても摘 果のできる程度の果実数が残って抢り，適正な着果数にす ることができたためと考兄られた。しかし，“早秋’はい びつな果形になりやすい品種であることから（山田ら， 2004），できるだけ多くの果実の中で摘果した方が果形の よい果実を残すことができる，そのことによって秀品率が 上がり, 農家所得の向上につながるため, 生理落果を抑え る意義は大きいと考兄られた。 

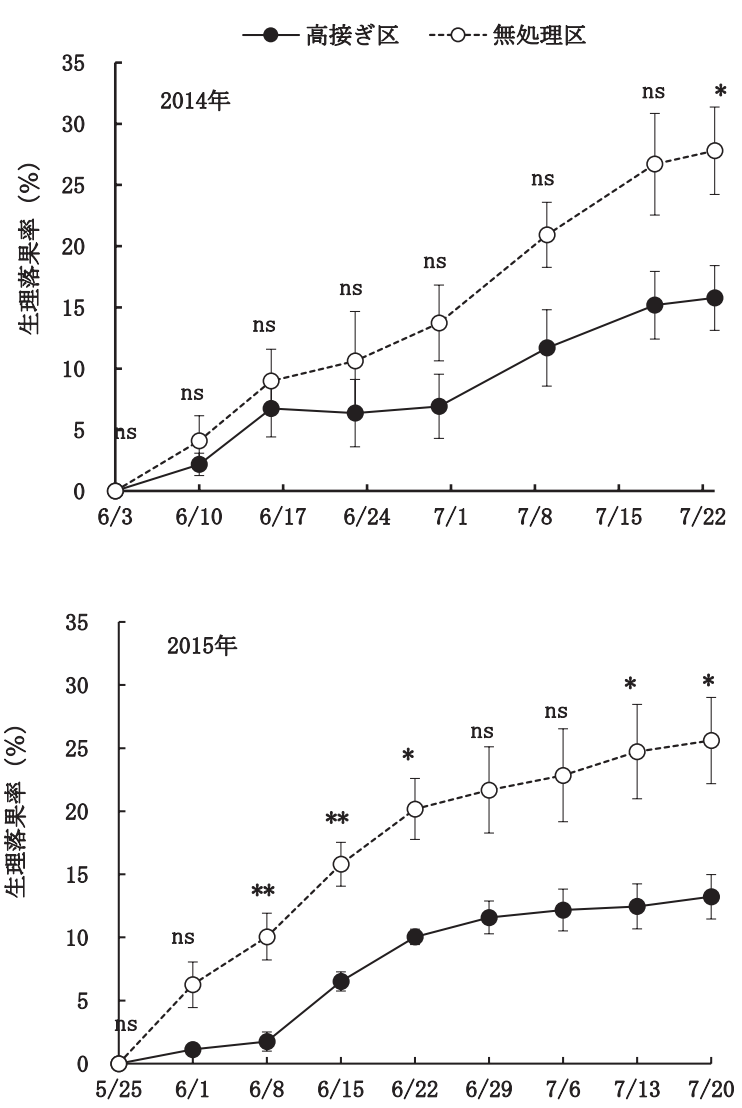

第2 図受粉用品種の高接ぎが生理落果率に及ぼす影響 （上段：2014年，下段：2015 年）

縦線は標準䛊差を示す $(n=3 \sim 4)$

アークサイン変換後 $\mathrm{t}$ 検定により, ns は有意差なし,

***1\%水準，*は $5 \%$ 水準で有意差あり

純花粉による人工受粉や受粉用品種の高接ぎによって, 生理落果防止にある程度の効果のあることが明らかになっ た。しかし, 生理落果の発生には日射量不足（梶浦, 1942a), 果実と枝葉間の養分競合（北島ら，1987）, 植物 ホルモン（傍島ら，1969; 壽松木ら，1989; 薬師寺・長谷, 1991）など多様な要因が関係しており，上述のとおり単一 の方法だけで防止することは難しい。 そこで, より安定し た生理落果防止を図るために, 主枝先端新梢長と生理落果
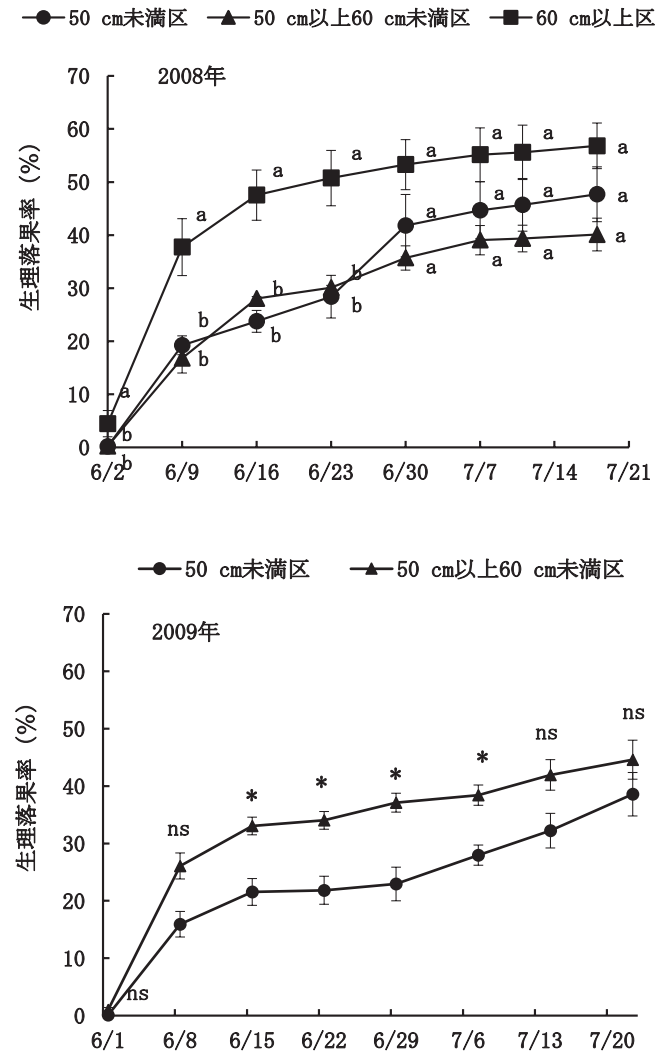

第3 図主枝先端新梢長別の生理落果率の推移

（上段 : 2008 年，下段 : 2009 年)

縦線は標準誤差を示す $(n=3 \sim 4)$

2008 年 : アークサイン変換後 Tukey の多重検定により, 同一調査日の異符号間に 5\%水準で有意差あり

2009 年：アークサイン変換後 $\mathrm{t}$ 検定により，ns は有意 差なし，*は5\%水準で有意差あり

との関係を調査した. 内向きの側枝および徒長枝のみを切 除する程度の弱剪定を行い，主枝先端新梢長が $50 \mathrm{~cm}$ 未満 であった樹体では，2008，2009年ともに，生理落果率を6 月下旬まで低く抑光られた。“早秋”の早期落果のらち，6 月に落果するほとんぞの果実は種子が形成されていないこ とから（千々和，2009），6月下旬までの生理落果率が低 かった原因は不受精落果が少なかったためと推察された.

第 4 表 受粉用品種の高接ぎが果実品質および樹当たりの収量に及ぼす影響

\begin{tabular}{|c|c|c|c|c|c|c|c|c|c|}
\hline & 試験区 & $\begin{array}{l}\text { 果重 }^{\mathrm{z}} \\
(\mathrm{g})\end{array}$ & $\begin{array}{c}\text { 果頂部果皮色 } \\
\text { (CC 值) }\end{array}$ & $\begin{array}{l}\text { 糖度 } \\
\left({ }^{\circ} \text { Brix }\right)\end{array}$ & $\begin{array}{l}\text { 果肉硬度 } \\
\left(\mathrm{kg} / \mathrm{cm}^{2}\right)\end{array}$ & $\begin{array}{l}\text { 種子数 } \\
\text { (個) }\end{array}$ & 奇形指数 $y$ & $\begin{array}{c}\text { 収穫果数／樹 } \\
\text { (果) }\end{array}$ & $\begin{array}{c}\text { 収量／樹 } \\
(\mathrm{kg})\end{array}$ \\
\hline \multirow{2}{*}{2014 年 } & 高接ぎ区 & 267.2 & 8.0 & 15.9 & 2.0 & 3.0 & 0.0 & 143.8 & 39.3 \\
\hline & 無処理区 & 246.4 & 7.6 & 16.9 & 1.9 & 2.6 & 0.1 & 113.7 & 26.0 \\
\hline \multicolumn{2}{|c|}{ 有意差 ${ }^{x}$} & ns & $\mathrm{ns}$ & $\mathrm{ns}$ & $\mathrm{ns}$ & ns & $\mathrm{ns}$ & $\mathrm{ns}$ & ns \\
\hline \multirow{2}{*}{2015 年 } & 高接ぎ区 & 279.5 & 7.3 & 15.0 & 1.7 & 2.2 & 0.2 & 117.8 & 34.1 \\
\hline & 無処理区 & 280.7 & 7.1 & 16.2 & 2.1 & 2.5 & 0.2 & 95.7 & 27.0 \\
\hline \multicolumn{2}{|c|}{ 有意差 ${ }^{x}$} & $\mathrm{~ns}$ & ns & ns & ns & ns & ns & ns & ns \\
\hline
\end{tabular}

z 摘果日にラベルした果実を調査

$\mathrm{y}$ 奇形指数は果実の奇形度を 0 (無) 〜 3 (甚) の 4 段階に評価した平均值

${ }^{\mathrm{x}} \mathrm{t}$ 検定により， ns は有意差なし $(\mathrm{n}=3 \sim 4)$ 
第 5 表 主枝先端新梢長別の樹当たりの結果母枝数，新梢数，二次伸長率おょび幹周

\begin{tabular}{|c|c|c|c|c|c|c|c|}
\hline & \multirow[b]{2}{*}{ 試験区 } & \multirow{2}{*}{$\begin{array}{c}\text { 結果母枝数/樹 } \\
\text { (本) }\end{array}$} & \multirow{2}{*}{$\begin{array}{c}\text { 新梢数／樹 } \\
\text { (本) }\end{array}$} & \multicolumn{2}{|c|}{ 不定芽由来 } & \multirow{2}{*}{$\begin{array}{c}\text { 二次伸長率 } \mathrm{y} \\
(\%)\end{array}$} & \multirow{2}{*}{$\begin{array}{l}\text { 幹周 } \mathrm{x} \\
(\mathrm{cm})\end{array}$} \\
\hline & & & & $\begin{array}{l}\text { 新梢数 / 樹 } \\
\text { (本) }\end{array}$ & $\begin{array}{c}\text { 新梢長 }{ }^{z} / \text { 樹 } \\
(\mathrm{cm})\end{array}$ & & \\
\hline \multirow{3}{*}{2008 年 } & $50 \mathrm{~cm}$ 未満区 & 20.5 & 200.5 & $0.8 \mathrm{a}^{\mathrm{w}}$ & $9.8 \mathrm{a}$ & 3.8 & 14.7 \\
\hline & $50 \mathrm{~cm}$ 以上 $60 \mathrm{~cm}$ 末満区 & 20.5 & 198.8 & $11.5 \mathrm{~b}$ & $311.0 \mathrm{~b}$ & 2.9 & 15.8 \\
\hline & $60 \mathrm{~cm}$ 以上区 & 14.8 & 163.8 & $6.0 \mathrm{ab}$ & $212.8 \mathrm{ab}$ & 2.4 & 14.7 \\
\hline & 有意差 ${ }^{v}$ & ns & ns & $*$ & $*$ & ns & ns \\
\hline \multirow{2}{*}{2009 年 } & $50 \mathrm{~cm}$ 未満区 & 37.8 & 179.5 & 13.3 & 341.0 & 0.2 & 15.9 \\
\hline & $50 \mathrm{~cm}$ 以上 $60 \mathrm{~cm}$ 末満区 & 24.3 & 142.0 & 16.7 & 574.3 & 1.2 & 18.9 \\
\hline & 有意差 u & ns & ns & ns & ns & ns & ns \\
\hline
\end{tabular}

$\mathrm{z}$ 不定芽由来の新梢の合計の長さ

$\mathrm{y}$ すべての新梢のらち，2008 年 6 月 26 日，2009年 6 月 25 日の時点で二次伸長していた割合

$\mathrm{x}$ 幹周は接ぎ木部の上部約 $15 \mathrm{~cm}$ の位置を測定

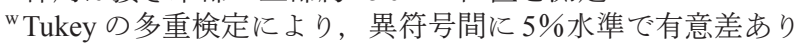

$\mathrm{v}$ 分散分析により，ns は有意差なし，*は $5 \%$ 水準で有意差あり $(\mathrm{n}=4)$

${ }^{\mathrm{u}} \mathrm{t}$ 検定により，ns は有意差なし（ $\mathrm{n}=3 \sim 4 ）$

第 6 表 主枝先端新梢長別の果実品質および樹当たりの収量

\begin{tabular}{|c|c|c|c|c|c|c|c|c|c|}
\hline & 試験区 & $\begin{array}{l}\text { 果重 }^{z} \\
(\mathrm{~g})\end{array}$ & $\begin{array}{c}\text { 果頂部果皮色 } \\
\text { (CC 值) }\end{array}$ & $\begin{array}{c}\text { 糖度 } \\
\left({ }^{\circ} \text { Brix }\right)\end{array}$ & $\begin{array}{l}\text { 果肉硬度 } \\
\left(\mathrm{kg} / \mathrm{cm}^{2}\right)\end{array}$ & $\begin{array}{l}\text { 種子数 } \\
\text { (個) }\end{array}$ & 奇形指数 ${ }^{y}$ & $\begin{array}{c}\text { 収穫果数／樹 } \\
\text { (果) }\end{array}$ & $\begin{array}{c}\text { 収量／樹 } \\
(\mathrm{kg})\end{array}$ \\
\hline \multirow{3}{*}{2008 年 } & $50 \mathrm{~cm}$ 未満区 & 258.0 & 6.3 & 16.0 & 2.1 & 1.7 & 0.2 & 43.3 & 10.9 \\
\hline & $50 \mathrm{~cm}$ 以上 $60 \mathrm{~cm}$ 未満区 & 256.8 & 6.6 & 16.7 & 2.0 & 1.3 & 0.2 & 43.5 & 11.0 \\
\hline & $60 \mathrm{~cm}$ 以上区 & 266.6 & 6.5 & 16.5 & 2.1 & 1.3 & 0.3 & 34.0 & 8.9 \\
\hline & 有意差 ${ }^{x}$ & ns & ns & ns & ns & ns & ns & ns & ns \\
\hline \multirow{2}{*}{2009 年 } & $50 \mathrm{~cm}$ 未満区 & 221.5 & 7.7 & 17.5 & 2.1 & 0.4 & 0.1 & 35.3 & 8.0 \\
\hline & $50 \mathrm{~cm}$ 以上 $60 \mathrm{~cm}$ 未満区 & 251.4 & 7.8 & 16.3 & 2.0 & 0.1 & 0.1 & 40.0 & 10.1 \\
\hline & 有意差 ${ }^{w}$ & ns & ns & ns & ns & ns & ns & ns & ns \\
\hline
\end{tabular}

z 摘果日にラベルした果実を調査

$\mathrm{y}$ 奇形指数は果実の奇形度を 0 (無) 〜 3 (甚) の 4 段階に評価した平均值

$\mathrm{x}$ 分散分析により, ns は有意差なし $(\mathrm{n}=4)$

${ }^{\mathrm{w}} \mathrm{t}$ 検定により，ns は有意差なし $(\mathrm{n}=3 \sim 4)$

しかし，7月以降は生理落果率が上昇した．主枝先端新梢 長に関わらず不定芽の発生や新梢の二次伸長が多かったこ とから，剪定強度を弱めて主枝先端新梢長を短くしても 7 月以降の生理落果を抑えることができなかったと考えられ た. 今後，不定芽由来の新梢が長大に伸長しないように， 捻枝や夏季剪定の実施，二次伸長した新梢の摘心など， 7 月以降の生理落果率を抑える方法を検討し, 生理落果の防 止技術の開発を図ることが必要である.

以上の結果から, ‘早秋’ の生理落果防止に向けて, 純花 粉による人工受粉, 受粉用品種の高接ぎおよび弱剪定に よって主枝先端の新梢長が短い樹の状態を保つことがポ イントになることが明らかになった. 今後, これらの方法 を組み合わせるとともに, 年次変動に対応できる生理落果 防止技術を開発し，“早秋’の結実安定技術を確立すること が重要である.

\section{摘 要}

‘早秋’ は極早生の完全甘ガキであること，果皮色は赤 く，良食味であることから，高い市場評価を得ている。し かし，生理落果の発生が多く，結実が安定しないことが課 題であった。 そこで，本研究では，人工受粉ならびに受粉 用品種の高接ぎが‘早秋’の生理落果に及ぼす影響を検討 した. ‘早秋’の人工受粉に適した花粉用品種は開花期の 合った“サエフジ’であった。 ‘サエフジ’の純花粉による 人工受粉や高接ぎは，年次変動によって効果に差を生じる が，生理落果防止にある程度の効果が認められた。 そこ で，より安定した生理落果防止を図るために，主枝先端新 梢長と生理落果との関係を調査した，弱剪定によって主枝 先端の新梢長が短い樹の状態を保つことによって，6月の 生理落果を抑えることはできるが，その後，生理落果率が 上昇した．以上のことから，“早秋”の生理落果防止に向 けて，純花粉による人工受粉，受粉用品種の高接ぎおよび 
弱剪定によって主枝先端の新梢長が短い樹の状態を保つこ とがポイントになることが明らかになった。 今後, これら の方法を組み合わせるとともに，年次変動に対応できる生 理落果防止技術を開発することが重要である.

\section{引用文献}

千々和浩幸. 2009. カキ二早秋. p. 48-52. 最新農業技術 果樹 vol. 2. 農文協. 東京.

独立行政法人農業 - 食品産業技術総合研究機構果樹研究 所. 2007. 育成系統適応性検定試験 - 特性検定試験調 查方法. p. 169-178.

文室政彦. 2003. 被覆条件下のベット栽培に打けるカキ ‘刀根早生”と“新秋”の結実に及ぼす摘蕾抏よび人工 受粉の影響. 園学研. 2: 179-182.

岐阜県. 2005. 主要園芸作物標準技術体系 果樹 - 特産 編. p. 1-19.

林 公彦. 2000. 生育と基本技術 生育過程と技術 開花 結実期 受粉樹の選定と配置. p. 185-187. 果樹園芸 大百科 6 力キ. 農文協. 東京.

堀江裕一郎・平島敬太・鶴 丈和. 1988. 力キ ‘伊豆” の 生理落果に及ぼす着果制限と人工受粉の影響. 福岡農 総試研報. B-8: 15-18.

梶浦 実. 1941. 柿の生理的落果に関する研究 II 授粉及 単為結実と落果との関係. 園学雑. 12: 247-283.

梶浦 実. 1942a. 柿の生理的落果に関する研究 III 降雨 及び乾燥と落果との関係. 園学雑. 13: 1-14.

梶浦 実. 1942b. 柿の生理的落果に関する研究 IV 開花 前に行ふ各種処理の落果に及ぼす影響. 園学雑. 13: 89-96.

北島 宣. 2000. 栽培の基礎 形態 - 生理 - 機能 果実発
育の生理 3. 種子形成と生理落果. p. 72-78. 果樹園 芸大百科 6 力キ. 農文協. 東京.

北島 宣・藤原敏郎 - 久木崎孝弘 - 石田雅士 - 傍島善次. 1987. 力キ結果枝の乾物蓄積量と生理落果との関係. 京都府大学報 (農). 39: 1-11.

新川 猛・尾関 健・加藤雅也・生駒吉織. 2008. 収穫後 の高温処理によるカキ “富有”果肉中のカロテノイド 含量の増強. 園学研. 7: 123-128.

傍島善次・石田雅士・清川薰雄・崎山 睦. 1969. カキの 生理的落果防止に関する研究 II 受粉扔よび GA 処理 が生理的落果に及ぼす影響ならびに果実内オーキシン の消長について．京都府大学報 (農). 21: 12-23.

杉村輝彦. 2008 . 力キ「早秋」の加温促成栽培. 農耕と園 芸. 63(11): 121-124.

壽松木 章・杉浦俊彦・村上ゆり子 ・間艼谷 徹. 1989. カキ果実の生理落果に関する生理学的研究（第 5 報） 果実のオーキシンと生理落果との関係. 果樹試報 A. 6: 31-37.

薬師寺 博・長谷嘉臣. 1991. カキ “富有”の早期落果と 植物ホルモン量に及ぼす種子含有数及び遮光の影響. 果樹試報. 19: 49-59.

山田昌彦・栗原昭夫・角 利昭. 1987. カキの結実性の品 種間差異とその年次変動. 園学雑. 56: 293-299.

山田昌彦・山根弘康・佐藤明彦・岩波 宏・平川信之・吉 永勝一 一小澤俊治・中島育子. 2004 . 力キ新品種 '早 秋’. 果樹研報. 3: 53-66.

矢野 隆・新開志帆・森口一志. 1999. 力キ “刀根早生” の生理落果抑制法に関する研究（第2 報）環状はく皮 方法の違いが生理落果抑制，果実形質に及ぼす影響. 愛媛果試研報. 13: 19-26. 